\title{
Outlining the therapeutic itineraries of children with disabilities in the professional health care subsystem
}

\author{
Construção dos itinerários terapêuticos de crianças com deficiência no subsistema profissional de cuidados em saúde
}

Construcción de los itinerarios terapéuticos de niños con discapacidad en el subsistema profesional de cuidados en salud

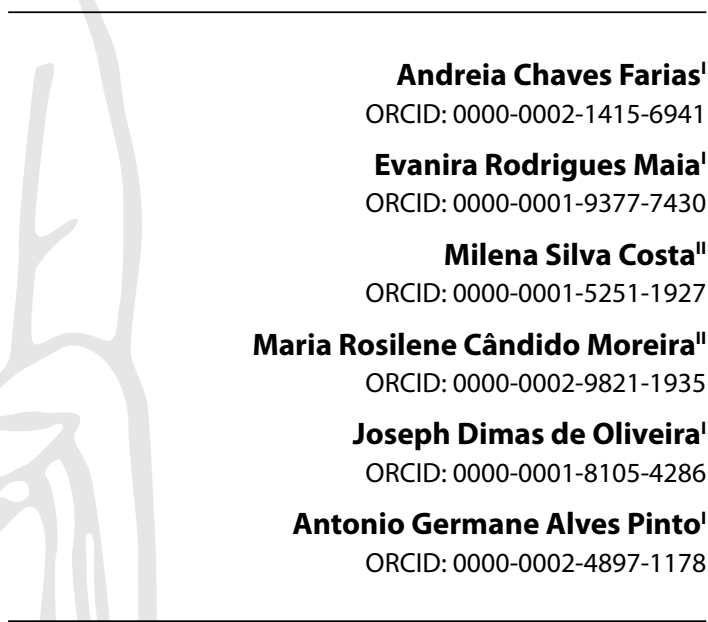

'Universidade Regional do Cariri. Crato, Ceará, Brazil. "Universidade Federal do Cariri. Barbalha, Ceará, Brazil.

How to cite this article: Farias AC, Maia ER, Costa MS, Moreira MRC, Oliveira JD, Pinto AGA. Outlining the therapeutic itineraries of children with disabilities in the professional health care subsystem. Rev Bras Enferm. 2022;75(3):e20210169. https://doi.org/10.1590/0034-7167-2021-0169

\section{Corresponding author: \\ Evanira Rodrigues Maia \\ E-mail: evaniramaia@gmail.com}

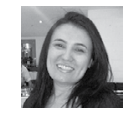

EDITOR IN CHIEF: Antonio José de Almeida Filho ASSOCIATE EDITOR: Fátima Helena Espírito Santo

Submission: 04-10-2021

Approval: 06-22-2021

\begin{abstract}
Objectives: to identify the outlining of therapeutic itineraries of families of children with disabilities in the professional health care subsystem. Methods: qualitative research carried out in two specialized services in the state of Ceará, with 41 family members interviewed using the life path technique and reports submitted to descending hierarchical classification and similitude analysis, with the help of the IRaMuTeQ software and the theoretical framework of health care systems. Results: the classes described the families' itineraries in five paths, related to faith, support structures, medical behaviors, professionals, and health services. The professional subsystem stood out as deficient in outlining the therapeutic itinerary for access to health care for children with disabilities, without promoting integration between services in the Care Network. Final Considerations: the families'therapeutic itineraries showed homogeneous discourse with themes related to the care of professionals and spiritual aspects. Descritores: Children With Disabilities; Health Services Needs and Demands; Access to Health Services; Child Care; Pediatric Nursing.
\end{abstract}

\section{RESUMO}

Objetivos: identificar a construção dos itinerários terapêuticos das famílias de crianças com deficiência no subsistema profissional de cuidados com a saúde. Métodos: pesquisa qualitativa realizada em dois serviços especializados no estado do Ceará, com 41 familiares entrevistados pela técnica de trajetória de vida, com relatos submetidos à classificação hierárquica descendente e análise de similitude, com auxílio do software IRaMuTeQ e do referencial teórico dos sistemas de cuidados com a saúde. Resultados: as classes descreveram o itinerário das famílias em cinco percursos, relacionados a fé, estruturas de suporte, condutas médicas, profissionais e serviços de saúde. O subsistema profissional destacou-se como deficitário no itinerário terapêutico para acesso ao cuidado com a saúde de crianças com deficiência, sem promover integração entre serviços da Rede de Atenção. Considerações Finais: o itinerário terapêutico das famílias apresentou discurso homogêneo com temas relativos ao cuidado dos profissionais e aspectos espirituais.

Descritores: Crianças com Deficiência; Necessidades e Demandas de Serviços de Saúde; Acesso aos Serviços de Saúde; Cuidado da Criança; Enfermagem Pediátrica.

\section{RESUMEN}

Objetivos: identificar la construcción de itinerarios terapéuticos de familias de niños con discapacidad, en el subsistema profesional de cuidados con la salud. Métodos: investigación cualitativa realizada en dos servicios especializados en Ceará, con 41 familiares entrevistados por la técnica de trayectoria de vida, con relatos sometidos a clasificación jerárquica descendente y análisis de similitud, con auxilio del software IRaMuTeQ y del referencial teórico de los sistemas de cuidados con la salud. Resultados: las clases describieron el itinerario de las familias en cinco trayectos, relacionados a fe, estructuras de soporte, conductas médicas, profesionales y servicios de salud. El subsistema profesional se destacó como deficitario en el itinerario terapéutico para acceso al cuidado con la salud de niños con discapacidad, sin promover integración entre servicios de la Red de Atención. Consideraciones Finales: el itinerario terapéutico de las familias presentó discurso homogéneo con temas relativos al cuidado de los profesionales y aspectos espirituales.

Descriptores: Niños con Discapacidad; Necesidades y Demandas de Servicios de Salud Accesibilidad a los Servicios de Salud; Cuidado del Niño; Enfermería Pediátrica. 


\section{INTRODUCTION}

Families of children with disabilities may be isolated and face discrimination, which can result in social exclusion and limited use of available resources ${ }^{(1)}$. Such problems occur because disabled children are in a situation of greater fragility and vulnerability due to their chronic health conditions. The therapeutic complexity of these children requires a greater demand for care and services when compared to those living without disabilities ${ }^{(2)}$.

In the family system, the resignification of functions and structure occurs to adapt to the child's needs. Difficulties begin with the child's diagnosis and the feelings that come with this new reality, causing suffering, denial, fear, and anguish. This situation prevents or limits the search for health services' guidance and care $^{(3)}$, being the object of study of this research.

Along this path, the families of children with disabilities seek people, places, services, and institutions to support and meet their demands. The therapeutic itinerary is established in the configuration of the Care Network and the quality of care through the available offers during the clinical and assistance path ${ }^{(4)}$. Professionals working in care must support families in facing their own health demands and those of the child with disabilities.

The concept of "therapeutic itinerary" goes through different historical moments. It is in the understanding of "illness behavior" by Mechanic \& Volkart ${ }^{(5)}$, in 1960, that the choices for treatment were made under the logic of consumption, with emphasis on the biomedical model and on the demands for services; and it gained an important contribution in the 1970s, with Arthur Kleinman, a psychiatrist and anthropologist, who emphasized the cultural influence on the patient's choices regarding the care path ${ }^{(6-7)}$.

The theoretical model of health care systems proposed by Kleinman presents two important concepts: that of "explanatory models", which refers to the conceptions of the disease and the forms of treatment used by all those engaged in a clinical process; and that of "Health Care system", which includes the places where individuals seek solutions to their health problems, being classified into three sectors (professional, consisting of the formal practices of medicine, such as biomedicine and homeopathy; popular, comprising of home and self-care; or folk, which corresponds to mystical and religious care practices) ${ }^{(8)}$.

The Care Network for People with Disabilities should expand access to services, qualify the service, and link people with disabilities and families to the care points in an articulated manner, with proper reception and risk classification. Priority is given to the monitoring of high-risk newborns with up to 2 years of life, the treatment of children with disabilities, and the appropriate support to families in the Lines of Care, defined as safe assistance flows that guarantee health care through integral actions ${ }^{(9-10)}$.

The dissonance is that there are weaknesses in the Lines of Care for children with disabilities. Difficulties of access and monitoring are noted in rehabilitation services not regulated by the Sistema Único de Saúde (SUS) [Brazilian Unified Health System], lack of coordination of care and/or linkage with Primary Health Care (PHC), failures in the reception and disarticulations in services are evident, which are aggravating factors and impediments to effective and comprehensive care ${ }^{(11)}$.
Thus, scientific investigations that seek to know what families experience in the care of children with disabilities, to (re)recognize the gaps found during the trajectory of the therapeutic itinerary are needed.Thus, this study raises the following research question: What is the therapeutic itinerary of families of children with disabilities in the light of the theoretical model of health care systems?

\section{OBJECTIVES}

To identify the outlining of therapeutic itineraries of families of children with disabilities in the professional health care subsystem in the light of the theoretical model of health care systems.

\section{METHODS}

\section{Ethical aspects}

The research adhered to the provisions of Resolutions 466/2012 and $510 / 2016$ of the National Health Council(12), and thus approved by the Ethics and Research Committee.

\section{Study design, period, and location}

Qualitative research, held from May to November 2019, in two specialized rehabilitation services: the Núcleo de Estimulação Precoce (NEP) [Early Stimulation Nucleus], a public service that works under the management of a public health consortium at a regional polyclinic; and the Associação de Pais e Amigos dos Excepcionais (APAE) [Association of Parents and Friends of the Exceptional].NEP and APAE are highly recognized children with disabilities care service providers, originating from the territory where the research was conducted and situated in municipalities to the south of the State of Ceará, Brazil.

In the elaboration and execution of the study, the recommendations of the Consolidated Criteria for Reporting Qualitative Research (COREQ) were used through a checklist made available by the EQUATOR Network (https://www.equator-network.org/).

\section{Sample, inclusion and exclusion criteria}

The research included the family members of children assisted in the rehabilitation services where the research data were collected. At the time of collection, 134 children with disabilities were registered in these services, with ages ranging from 0 to 9 years old. As inclusion criteria, the direct involvement in the daily care of the child and being domiciled in a municipality located in the southern region of the state of Ceará were considered. Family members who had a verbal and/or intellectual disability that made it impossible to report and participate in the research were excluded.

\section{Study protocol}

For data collection, a semi-structured interview script composed of sociodemographic information was used; and the in-depth interview, focusing on the experiences lived in the therapeutic itinerary of children with disabilities, based on the 
guiding question: "Tell me about the path in the search for care for children with disabilities".

The interviews were carried out after approaching the research locations and explaining the steps to the participants. Data collection took place in the morning, in a private room, through individual sessions lasting an average of 40 minutes. A research-dedicated cell phone with a digital voice recorder was used to avoid the risk of sharing information.

In this study, code saturation was adopted, which is defined as the point at which no additional problems are identified and the data coding system is stabilized. The interviews were closed after the dialogue codes/themes were repeated and without any new data ${ }^{(13)}$.

\section{Analysis of results}

The life history reports were transcribed to a file in the Libre Office Writer program, version 5.4, being coded according to the numerical sequence of the interviews and the respective specialized service to which each family member was linked, forming a database with two textual corpora: NEP itinerary and Apae itinerary.

Each corpus was submitted to the descending hierarchical classification (DHC), with the aid of the Interface de R pour les Analyzes Multidimensionnelles de Textes et de Questionnaires (IRaMuTeQ) software, version 0.7 , alpha 2. This free, open code tool is anchored in the $\mathrm{R}$ software and in the Python programming language to enable different modes of simple analysis, such as basic lexicography, or multivariate analysis ${ }^{(14)}$, such as those adopted in this study.

In DHC, IRaMuTeQ performs the fractionation of the corpus through statistical calculations, originating text segments (TSes), which are classified according to their vocabularies, resulting in classes that have similar vocabulary among themselves in the same class and different in the TSes of other classes. Thus, the words contained in the same class assume this representation, as it is considered that, when used in a similar context, they are associated with the same lexical world, composing specific mental worlds or semantic contexts of a same representation. It is noteworthy that it is considered a good use of the corpus when the retention percentage of TSes is equal to or greater than $75 \%^{(14-15)}$.

In order to obtain a panorama that would express the global itinerary of the families, the textual corpora were unified and subjected to similarity analysis, which is based on the theory of graphs, making it possible to identify the co-occurrences between words, which indicate the connection between them, helping in the identification of the structure of the investigated phenomenon. Delineated in the form of a co-occurrence tree, this structure is presented by an image containing colored groupings called "communities", interconnected by vertices that vary in size and position and announce different degrees of interconnection ${ }^{(16)}$.

The theoretical model of health care systems supported the interpretive analysis of the material originated in the IraMuTeQ and constituted the theoretical-methodological framework that guided the study. This framework consists of three social subsystems, which consist of popular, folkloric (folk), and professional subsystems. For this study, the professional subsystem was considered one that includes both the professionals of Western scientific medicine and traditional healing systems ${ }^{(6)}$. This choice is due to the fact that this analysis favors the identification of health actions for children with disabilities in the services, through the therapeutic itinerary.

\section{RESULTS}

Forty-one family members participated in the study, all women; being: 37 mothers, 2 adoptive mothers, 1 aunt, and 1 grandmother. The "homemaker" occupation predominated, with ages between 30 and 39 years old, complete high school degree, Catholic, married or in a stable union, and with a family income of one minimum wage (BRL R\$998.00, in 2019), earned through the Benefício de Prestação Continuada (BPC) [Continuous Cash Benefit], which, at times, was complemented by informal and sporadic work. Of the participants, 20 were interviewed at the NEP; and 21 in Apae.

\section{NEP Itinerary}

The corpus from families whose children were assisted in the NEP was divided into 473 TSes, and the DHC retained 376 of them $(79.5 \%$ of the total), originating four classes. Initially, the corpus was divided establishing the class 4, "support path"; in the second partition, class 3, "path through medical conduct", was separated from the others; and, in the third partition, there was a separation of class ones, "path through health services", and 2 , "path for health professionals", ending the process (Figure 1).

The lexical terms grouped within the respective $\mathrm{DHC}$ classes, when examined in the light of the theoretical framework of health care systems, allowed the elucidation of the meanings contained therein and outlined the naming of the four trajectories taken by families registered in the NEP regarding their search for care with the disabled child.

Class 4 retained $27.4 \%$ of the TSes and concentrated the aspects on the professional subsystem, receiving the name "support path". Spiritual, family, and social support, as well as the network support, were the components taken from the itinerary of families that stood out in this class.

I only thank the good things that God brings in my daughter's life. (E15, NEP)

With the help of the family, I was able to buy his orthosis because we always had this difficulty in getting things for him. (E06, NEP)

Class 3, with the highest percentage of representation in the corpus (27.9\%), evidenced components related to clinical manifestations, diagnosis, and disability-related medical interventions, being called "path through medical conduct". Medication, cesarean section, and Zika virus were the most frequent terms in this class.

The problem was already there at childbirth, it was negligence, because his case was to be cesarean right away and he tried to make it a normal birth, that's where he got sick. (E13, NEP)

[...] I told him that his head wasn't growing, the nurse checked his head every month, but didn't say it, it wasn't growing at all. (E10, NEP) 


\begin{tabular}{|c|c|c|c|c|c|c|c|c|c|c|c|}
\hline \multicolumn{3}{|c|}{$\begin{array}{c}\text { Class } 1 \\
\text { (88 TSes - 23.4\%) }\end{array}$} & \multicolumn{3}{|c|}{$\begin{array}{c}\text { Class } 2 \\
\text { (79TSes - 21.0\%) }\end{array}$} & \multicolumn{3}{|c|}{$\begin{array}{c}\text { Class } 3 \\
\text { (105 TSes - 27.9\%) }\end{array}$} & \multicolumn{3}{|c|}{$\begin{array}{c}\text { Class } 4 \\
\text { (104TSes - 27.4\%) }\end{array}$} \\
\hline form & $f$ & $\left(x^{2}\right)$ & form & $f$ & $\left(x^{2}\right)$ & form & $f$ & $\left(x^{2}\right)$ & form & $f$ & $\left(x^{2}\right)$ \\
\hline surgery & 22 & $(54.7)$ & speech therapist & 17 & (61.4) & general_hospB & 09 & (23.8) & son & 23 & (41.9) \\
\hline neuro_center & 16 & $(45.2)$ & neurologist & 28 & $(44.3)$ & medication & 08 & (21.2) & God & 14 & (33.7) \\
\hline orthopedist & 12 & (22.1) & physical therapist & 10 & (38.6) & cesarian section & 06 & (15.7) & health & 10 & (19.2) \\
\hline SUS* & 07 & (18.7) & nurse & 09 & (25.2) & convulsion & 05 & (13.8) & family & 06 & (15.9) \\
\hline infA_hosp & 09 & $(18.0)$ & occupational_therapy & 06 & (22.9) & diagnosis & 05 & (13.3) & thank_God & 11 & (14.1) \\
\hline infB_hosp & 04 & (13.2) & pediatrician & 15 & (19.3) & deficiency & 06 & (11.8) & husband & 05 & (13.3) \\
\hline appointment & 12 & (12.6) & nutritionist & 05 & $(19.1)$ & zika & 10 & (11.6) & advocacy & 05 & (13.3) \\
\hline general_hospA & 08 & $(10.9)$ & medical_school & 07 & (17.9) & hospital & 13 & (11.3) & mass & 04 & (10.6) \\
\hline referral & 06 & $(7.7)$ & polyclinic & 07 & (14.9) & tomography & 06 & $(9.0)$ & judge & 04 & (10.6) \\
\hline \multirow[t]{3}{*}{ Health_secretariat } & 09 & (3.9) & psychologist & 04 & (10.6) & microcephaly & 11 & $(4.8)$ & child_services & 04 & (10.6) \\
\hline & & & follow-up & 12 & $(8.7)$ & $\mathrm{ESF}^{\dagger}$ & 03 & (4.5) & city hall & 05 & (9.5) \\
\hline & & & & & & polyclinic & 03 & $(4.5)$ & & & \\
\hline
\end{tabular}

* SUS - Sistema Único de Saúde (Unified Health System); † ESF - Estratégia Saúde da Família (Family Health Strategy).

Figure 1 - Dendrogram of the descending hierarchical classification of the itinerary corpus of children assisted in the Núcleo de Estimulação Precoce (Early Stimulation Nucleus)

Class 1, with $23.4 \%$ of representation in the corpus, listed the reference health services that were accessed by the families on their itineraries. This class was called "path through health services" and presented the Neurorehabilitation Center, SUS, and two children's hospitals as highlighted services.

She goes to the Sarah Neurorehabilitation Center and has already been to Albert Sabin Hospital. In this one, she went to the neurologist and orthopedist, who performed the surgery. From there, she'll go to the Sarah Neurorehabilitation Center for child rehabilitation. (E12, NEP)

Class 2, called "path for health professionals", obtained 21\% representation in the corpus and listed the main specialties related to the care and monitoring of children with disabilities who were part of the families' itinerary, with emphasis on speech therapy, neurology and physiotherapy.
Only after he entered the NEP was that he had the assessment with the professionals, but not the neurologist, only the speech therapist, occupational therapist, and nurse. (E04, NEP)

\section{Apae ltinerary}

The corpus from families whose children were assisted in Apae was divided into 593 TSes, and the DHC retained 535 of them ( $90.2 \%$ of the total), originating five classes. Initially, the corpus was divided into two subcorpora, originating, on the one hand, class 2"path to health services", and 3, "path for health professionals involved", in opposition to the others; in the second partition, class 5, "path to medical conduct", was separated from class 1 , "support path", and 4, "faith path"; in the third partition, there was a separation of classes 1 and 4; and, in the fourth partition, classes 2 and 3 were separated (Figure 2).

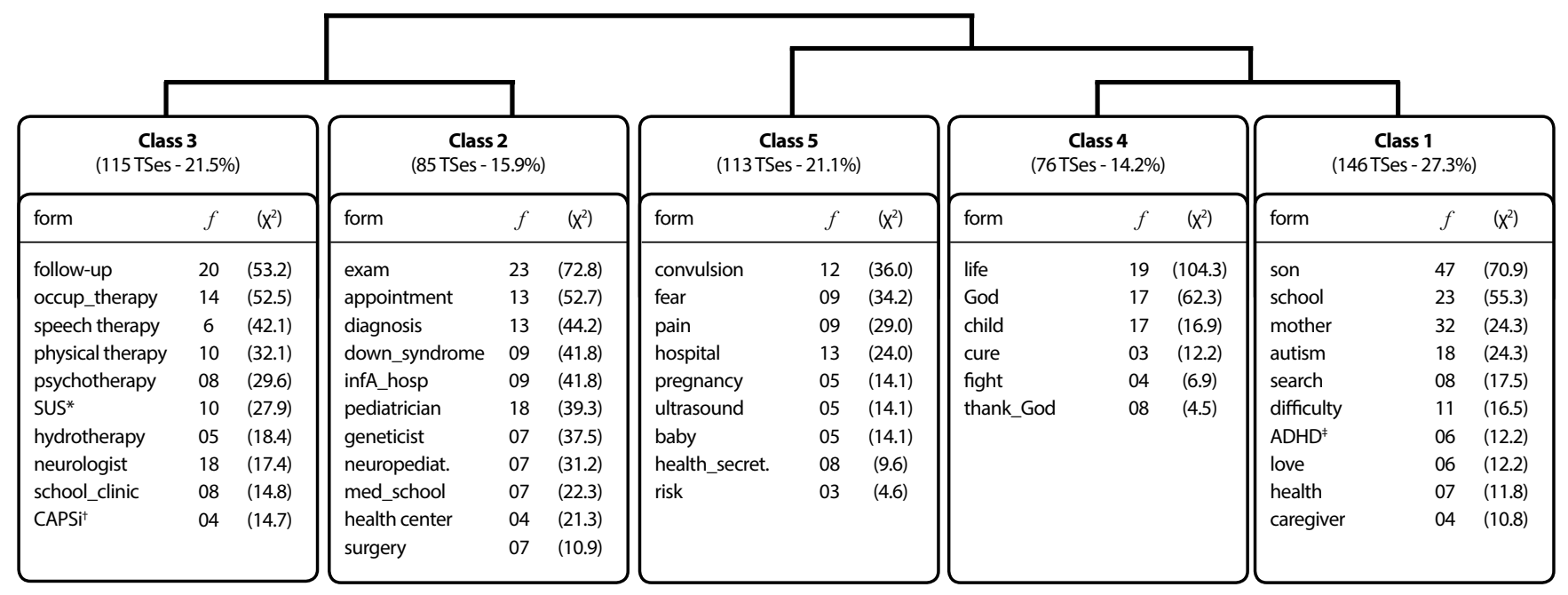

*SUS-Sistema Único de Saúde [Unified Health System]; † CAPSi-Centros de Atenção Psicossocial Infanto juvenil [Child and Youth Psychosocial Care Centers]; $¥$ ADHD-attention deficit hyperactivity disorder. Figure 2 - Dendrogram of the descending hierarchical classification of the itinerary corpus of children assisted at Apae 
Like the NEP itinerary corpus DHC, the words grouped in the classes of the Apae itinerary corpus DHC, after approximation to the model of health care systems, made possible the delineation of five trajectories carried out by the families registered in the institution, while seeking health care for their disabled child.

Class 5, representing $21.1 \%$ of the corpus, encompassed aspects related to the clinic involved in the disability, being called a "path for medical conducts". Convulsion, fear, and pain were the most referred-to symptoms in this class.

There was nothing abnormal on that day; and, at night, he had a convulsion that caused a respiratory arrest. In this convulsion, if I didn't live very close to the hospital, we would have lost him. The doctor himself told us that. (E38, Apae)

Class 1, with the highest percentage of representation in the corpus (27.3\%), brought the elements of the "support path" in the families' itinerary, especially school support and coping with the difficulties experienced in this context.

Nowadays they have a psychologist, because the schools are obliged to have one, but I was the first mother who brought in a medical report, as there are mothers who omit the son's report because the family also suffers. (E37, Apae)

Class 4 obtained $14.2 \%$ retention of the TSes, highlighting the role of spirituality as positive strengthening in the daily struggle for the health of the disabled child; and received the denomination of "faith path".

I only have to thank this space for us, mothers, to be able to vent for a minute, because life is not easy, but God knows all things. The support he gives us is hope through our children. (E29, Apae)

Class 2, with $15.9 \%$ representation in the corpus, covered the "path for health services", by performing the disability examination, consultation, and diagnosis. Down syndrome was the pathology mentioned in this class.

So, the only thing the hospital did was the karyotype, to know which of the three syndromes he had; and, when I left there, I was referred to the pediatrician. And in the first consultation she confirmed that he had Down syndrome. (E22, Apae)

Class 3, which obtained $21.5 \%$ retention, evidenced that neurologists, speech therapists, and occupational therapists were among the most frequent professionals in the itinerary of the children assisted in Apae.

We went to seek physiotherapy treatment, that's how I learned about Apae. It was here that he began the treatment; here, I also met the school clinic where he does his treatment; in addition to motor physiotherapy, he does hydrotherapy and respiratory physiotherapy, and here he also has speech therapist follow-up. (E36, Apae).

The professional subsystem trailed by the families was represented in the tree of similitude, in which four peripheral communities were structured to a large central community. The first brought the terms "Apae" in approximation with "school of medicine", through which it has established communication with "geneticist", "school clinic", and "occupational therapy", evidencing the institutions involved and the therapeutic activities offered to the children. The second community referred to rehabilitation health professionals, especially "speech therapist" and "occupational therapist". The third community brought rehabilitation therapies. The fourth community presented primary care institutions ("health center"), Secondary Care and Tertiary Reference Care, represented by the terms "state pediatric hospital", "center for neurorehabilitation" and "neonatal ICU", evidencing the detachment between neonatal intensive care unit (ICU) and Primary Care (Figure 3).

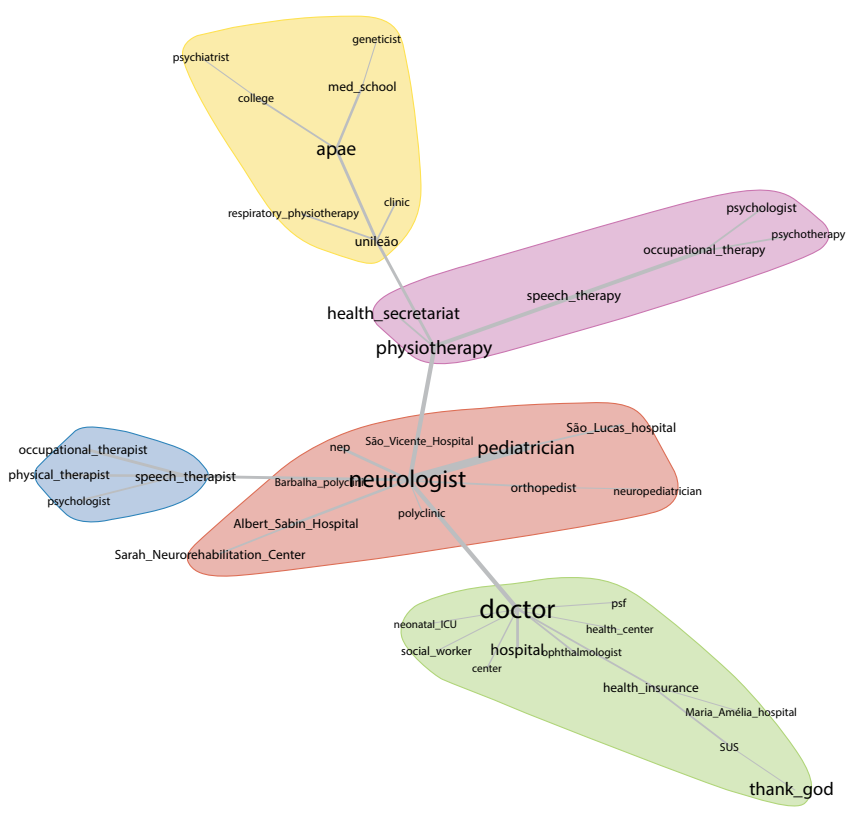

Figure 3 - Similitude tree of the therapeutic itinerary of family members of children with disabilities, 2019

\section{DISCUSSION}

The disabled child constitutes a challenging phenomenon for the family, as it leads to a search for care actions in different spaces, through different social actors, who represent the paths of their therapeutic itinerary.

A review of the national literature points out that spiritual/ religious support is recurrent in the interviewees' speeches about the therapeutic itineraries related to their illnesses or health problems. Aspects linked to spirituality appeared in the speeches of the families of children with disabilities and were unveiled in their speeches of gratitude for individualized support and their individual relationship with the supernatural ${ }^{(17)}$. In fact, nowadays, spiritual and/or religious institutions provide support or therapeutic actions to people and/or families.

In the case of children with chronic health problems, there is a search for spiritual support to face health problems ${ }^{(18)}$. Among family members of children with mental health problems and special health needs, studies show the difficulties for comprehensive 
care in a network due to the reduced offer of services and the fragility of the bond between teams and families in the search for care ${ }^{(19-20)}$.

Through the spiritual dimension, experiences of faith and gratitude to God are lived, injecting into the family the necessary vitality to face the child's health improvement/worsening, through prayers and rituals common in the popular subsystem. The mother attributes, first, to God, the gains in neuropsychomotor development and designates herself as special when chosen by Him to be the mother of a child with a disability, attributing this occurrence to the divine will(21-22).

It was observed as a theme within the families' speeches, aspects related to the disabled child's condition (clinical manifestations, diagnosis, and medical interventions) related to events such as pregnancy, cesarean section, the presence of seizures, consultations with specialists, and exams such as ultrasonography. Studies with family members bring similar data, showing that the therapeutic itinerary of families with children with cancer, microcephaly and/ or deafness is built more with health professionals who act as a gateway to the health system ${ }^{(23-24)}$.

The therapeutic itinerary unveiled by the families of children with disabilities highlights the professional subsystem for accessing children's care, characterized by public, private (schoolclinics), and philanthropic health services, with the presence of health professionals, physicians, and non-physicians. Entry into the subsystem takes place through Secondary Care, with the involvement of specialist medical professionals (pediatricians and neurologists), who carry out diagnostic investigations and/ or referrals to rehabilitation services.

Although health professionals and services are the main means of access for families to institutions, there are gaps in the management of cases, which leads to delays in diagnosis, monitoring of chronic diseases, and for commencing the child's rehabilitation. From the perspective of the health care model, the professional subsystem encompasses legally recognized professions; and, in the case of this study, this is the subsystem that predominates in the statements of family members ${ }^{(6)}$. A similar result was demonstrated in a study of the local rehabilitation networks' user profiles ${ }^{(23)}$.

In western or westernized societies, the professional subsystem tends to predominate in relation to popular and folk subsystems, as was the case in this study. However, the data show that the most significant terms were those related to the hospital, followed by those related to exams and, finally, to PHC. This denotes a model of professional care centered on the hospital, on the use of technology aimed at childbirth (cesarean section), on late diagnosis of diseases, in critical and crisis situations (convulsion), and on the sometimes abrupt discovery of disability. This reality, in the theoretical conception of the health care model, points to the way in which a given health system articulates the concepts of "health", "disease", and "care" with cultural language, being that the relationship between the three elements gives meaning to the whole ${ }^{(6)}$.

Although the disability is not limited to a biomedical perspective, the definition of its etiology contributes to attention to the biological needs of the child who presents it and the therapeutic path to be followed, enabling an effective care plan in the professional care subsystem. Furthermore, it provides information that helps the family to accept the child's condition ${ }^{(25)}$.

Mothers, fathers, and family members are the first to notice the signs of a delay in the child's development. Early intervention in child development requires an interdisciplinary look at the family-centered ways of acting and working ${ }^{(26)}$. The suffering of parents, reported by caregivers, in view of the child's disability diagnosis, is real and permeates a feeling similar to grief. This process is permeated by shock, fear, sadness, anger, and guilt, which are presented in the perspective of facing reality ${ }^{(27)}$.

In his theory, Kleinman ${ }^{(6)}$ clarifies that, despite the fact that healing is one of the functions of the health system, it is not always possible. Thus, one must "adjust expectations, beliefs, behavior, and outcome assessments", especially from the point of view of therapeutic efficacy in certain diseases, such as disability. Thus, the competence and sensitivity of the health professional responsible for communicating the diagnosis are essential for adequate family support and affect the elaboration of the feelings experienced by parents and the roles to be played by them, towards care and inclusion ${ }^{(27)}$.

Access to the professional subsystem was sought at the first signs of delay in neuropsychomotor development, by the families and not the professionals. However, it was marked by "stumbling through health services"(28) due to the non-implementation of safe and effective care guidance flows, which, associated with the scarcity of services, resulted in difficult access. A similar finding was elucidated by caregivers in a study that assessed how difficult it is for children with disabilities to access the Care Network and showed that the time it took for inclusion of children in these services was long, whether they were regulated or not ${ }^{(29)}$.

In the present study, the implementation of the NEP expanded the offer of rehabilitation services closer to home and in a regulated manner. However, a fine line was identified in the interaction between this service and PHC, demonstrated in access by spontaneous demand and/or referrals from other Secondary Care services, without proper coordination of care, which translates into harm to the proper establishment of care flows ${ }^{(28)}$.

Kleinman ${ }^{(6)}$ reinforces that communication is crucial for the satisfactory outcome of health problems and greatly influences the adherence, adequacy, and satisfaction of users with health services. In the studied scenario, communication failures in the care network negatively influenced the clinical results and the care provided to such children.

The profile presented is consistent with the construction of therapeutic itineraries for families in the professional subsystem in caring for the health of children with disabilities. Such therapeutic itineraries are marked by the inexistence or failures in care flows, in accessibility, in articulation, in the ordering and in the integrality of the care network. The statements are representative of the situation highlighted and described in the caregivers' oral history.

The entry into the formal subsystem took place through specialized care, with consultations with pediatricians and/or neurologists, demonstrating the weakness of PHC in the assessment of the child, identification of the problem, coordination of care, and organization of the network. The therapeutic itinerary was built essentially by the mother and the child and marked by difficulties related to the provision of services due to their 
scarcity, absence of a specific line of care, in addition to the difficult access to assistive technologies and the existence of barriers to school inclusion.

The analysis of the therapeutic itinerary revealed the dense participation of educational institutions, school clinics, and medical schools in the provision of rehabilitation and specialized consultation. It reinforced the participation of Apae and the incipient involvement of the CAPSi in the rehabilitation of children with intellectual disabilities and/or autism spectrum disorder. It should be noted that access to educational services, as well as to Apae, is not regulated and occurs outside the SUS, through informal referrals and/or mediated by the approximation between professionals and between the professionals and the services.

With this view, it is understood that the lack of integration between the Care Network services and the failure to visualize its design by the professionals responsible for the care of these children imply damages to access, equity, integrality, and effectiveness of care, as well as highlights the fragility of the structure and organization of the existing network.

\section{Study limitations}

In the development of daily care investigative scopes, the qualitative look can be limited by the focal interpretation of a specific context, but it is expanded by the intentional depth of the relationships. The study was developed in two rehabilitation services, one public and the other philanthropic; however, during its development, other rehabilitation services were identified, such as teaching clinics, so that the non-inclusion of these others constituted a limitation of the study. Research is recommended in new scenarios and with audiences involved with the theme, such as health and education professionals, other family members (other than mothers), and children (older children) with disabilities.

\section{Contributions to the field of nursing, health, or public policy}

The research shows the construction of a therapeutic itinerary strongly linked to the professional subsystem, initially centered on the doctor and the hospital, and then on health rehabilitation services, with spirituality as a source of support. In this sense, this work contributes to unveil this scenario and exposes the fragmentation of the care network for children with disabilities, therefore it can help in the development of policies that ensure comprehensive care for this population. Furthermore, this study innovates with the electronic and systematic instrumentalization of information, which, together with the experiences between participants and researchers, exalts health and care needs as the Health Care target.

\section{FINAL CONSIDERATIONS}

The construction of the therapeutic itinerary of families of children with disabilities, in light of the theoretical model of health care systems, occurs more evidently through the professional subsystem, with some aspects of the popular subsystem, while the folk subsystem was not identified.

Although the professional subsystem was predominant, it was characterized as deficient, as it did not promote integration between network services. Entry into the formal subsystem occurred through specialized care built essentially by the mother and child and was marked by difficulties related to the provision of services.

\section{SUPPLEMENTARY MATERIAL}

The work was extracted from the dissertation - Therapeutic Itinerary of Families of Children with Disabilities available at: https://renasf.fiocruz.br/sites/renasf.fiocruz.br/files/disseracoes/2019_URCA_Disserta\%C3\%A7\%C3\%A3o_Andreia\%20 Chaves\%20Farias.pdf

\section{REFERENCES}

1. Missel A, Costa CC, Sanfelice GR. Humanization of health and social inclusion in caring for people with physical disabilities. Trab Educ Saúde. 2017;15(2):575-97. https://doi.org/10.1590/1981-7746-sol00055

2. Figueiredo SV, Sousa AC, Gomes IL. Children with special health needs and family: implications for Nursing. Rev Bras Enferm. 2016;69(1):8895. https://doi.org/10.1590/0034-7167.2016690112i

3. Santos KH, Marques D, Souza AC. Children and adolescents with cerebral palsy: analysis of care longetudinality. Texto Contexto Enferm. 2017;26(2):e00530016. https://doi.org/10.1590/0104-07072017000530016

4. Cerqueira MM, Alves RO, Aguiar MG. Experiences in the therapeutic itineraries of mothers of children with intellectual disabilities. Ciênc Saúde Coletiva. 2016;21(10):3223-32. https://doi.org/10.1590/1413-812320152110.17242016

5. Sirri L, Fava GA, Sonino N. The unifying concept of illness behavior. Psychother Psychosom. 2013;82(2):74-81. https://doi.org/10.1159/000343508

6. Kleinman A. Concepts and a model for the comparison of medical systems as cultural systems. Soc Sci Med. 1978;12(2B):85-95. https://doi. org/10.1016/0160-7987(78)90014-5

7. Siqueira SM, Jesus VS, Camargo CL. The therapeutic itinerary in urgent/emergency pediatric situations in a maroon community. Ciênc Saúde Coletiva. 2016;21(1):179-89. https://doi.org/10.1590/1413-81232015211.20472014

8. Cabral AL, Martinez-Hemáez A, Andrade El, Cherchiglia ML. [Therapeutic itineraries: state of the art of scientific production in Brazil]. Ciênc Saúde Coletiva. 2011;16(11):4433-42. https://doi.org/10.1590/S1413-81232011001200016. Portuguese.

9. Ministério da Saúde (BR). Portaria n. 793/2012. Institui a Rede de Cuidados à Pessoa com Deficiência no âmbito do Sistema Único de Saúde [Internet]. Brasília, DF: Ministério da Saúde; 2012 [cited 2020 Dec 20]. Available from: https://bvsms.saude.gov.br/bvs/saudelegis/gm/2012/ prt0793_24_04_2012.html 
10. Pessôa LR. Manual do gerente: desafios da média gerência na saúde [Internet]. Rio de Janeiro: Escola Nacional de Saúde Pública Sergio Arouca; 2011 [cited 2020 Dec 20]. Available from: http://www5.ensp.fiocruz.br/biblioteca/dados/txt_51893713.pdf

11. Farias AC, Moreira MR, Costa MS, Oliveira JD, Pinto AG, Maia ER. Itinerário terapêutico de famílias de crianças com deficiência à luz do modelo teórico dos sistemas de cuidados à saúde. New Trends Qual Res. 2020;3:359-71. https://doi.org/10.36367/ntqr.3.2020.359-371

12. Ministério da Saúde (BR). Conselho Nacional de Saúde. Resolução 466, de 12 de dezembro de 2012. [Internet]. Brasília, DF: Ministério da Saúde; 2013 [cited 2020 Dec 20]. Available from: https://bvsms.saude.gov.br/bvs/saudelegis/cns/2013/res0466_12_12_2012.html

13. Hennink MM, Kaiser BN, Marconi VC. Code saturation versus meaning saturation: how many interviews are enough? Qual Health Res. 2017;27(4):591-608. https://doi.org/10.1177/1049732316665344

14. Camargo BV, Justo AM. IRAMUTEQ: um software gratuito para análise de dados textuais. Temas Psicol. 2013;21(2):513-8. https://doi. org/10.9788/TP2013.2-16

15. Souza JM, Machado FR, Antunes PP, Santos AC, Levandoswki DC, Oliveira AA. Qualidade de vida e sobrecarga de cuidadores de crianças com paralisia cerebral. Rev Bras Promoç Saúde. 2018;31(3):1-10. https://doi.org/https://doi.org/10.5020/18061230.2018.7748

16. Camargo BV, Justo AM. Tutorial para uso do software de análise textual IRAMUTEQ [Internet] Florianópolis: Laboratório de Psicologia Social da Comunicação e Cognição; 2018 [cited 2020 Dec 20]. Available from: http://www.iramuteq.org/documentation/fichiers/ tutoriel-en-portugais

17. Demétrio F, Santana ER, Pereira-Santos M. The Therapeutic Itinerary in Brazil: systematic review and meta-synthesis from the health negative and positive conceptions of health. Saúde Debate. 2019;43(esp-7):204-21. https://doi.org/10.1590/0103-11042019s716

18. Lima BC, Silva LF, Góes FG, Ribeiro MT, Alves LL. The therapeutic pathway of families of children with cancer: difficulties faced in this journey. Rev Gaúcha Enferm. 2018;39:e20180004. https://doi.org/10.1590/1983-1447.2018.20180004

19. Delfini PS, Bastos IT, Reis AO. Family odysseys: the search for infant mental health care. Cad Saúde Pública. 2017;33(12):e00145816. https:// doi.org/10.1590/0102-311x00145816

20. Luz RO, Pieszak GM, Arrué AM, Gomes GC, Neves ET, Rodrigues AP. Therapeutic itinerary of families of children with special health needs. Rev Rene. 2019;20:e33937. https://doi.org/10.15253/2175-6783.20192033937

21. Tomaz RV, Santos VA, Silva LR, Germano CM, Melo DG. Impact of moderate intellectual disability on the dynamics and quality of family life: a qualitative clinical study. Cad Saúde Pública. 2017;33(11):e00096016. https://doi.org/10.1590/0102-311x00096016

22. Carvalho A, Coelho V, Tolocka R. Professores de educação infantil e temas sobre inclusão de crianças com deficiência no ensino regular. Educ Pesqui. 2016;42(3):713-26. https://doi.org/10.1590/S1517-9702201609151344

23. Souza MJ, Morais AC, Lima IS, Mascarenhas JS, Lima MM, Amorim RC. Therapeutic itinerary of families of children with microcephaly. Rev Baiana Enferm. 2019;33:e32966. https://doi.org/10.18471/rbe.v33.32966

24. Vianna NG, Lima MC, Andrade MG. Therapeutic itinerary of a deaf child in the Network of Health Care. Distúrb Comun. 2020;32(1):73-86. https://doi.org/10.23925/2176-2724.2020v32i1p73-86

25. Melo DG, Pilotto RF, Rodrigues SA, Avó LR, Germano CM. Etiological investigation in situations of intellectual disability or global developmental delay. Saúde Desenvolv Hum. 2018;6(3):73-85. https://doi.org/10.18316/sdh.v6i3.4217

26. Franco V. Becoming father/mother of a child with serious problems of development. Educ Rev. 2016;59(1):35-48. https://doi. org/10.1590/0104-4060.44689

27. Oliveira IG, Poletto M. Emotional experiences of mothers and fathers of children with disabilities. Rev SPAGESP [Internet]. 2015 [cited 2020 Dec 20];16(2):102-19. Available from: http://pepsic.bvsalud.org/pdf/rspagesp/v16n2/v16n2a09.pdf

28. Mendes EV. O acesso à atenção primária à saúde. Brasília, DF: Conselho Nacional dos Secretários de Saúde; 2016.

29. Buspo Jr JP, Bonfatti RJ. A Estratégia de Saúde da Família na garantia do acesso da criança com deficiência à rede de atenção [Dissertação] [Internet]. Fundação Oswaldo Cruz. Rio de Janeiro; 2016 [cited 2020 Dec 20]. Available from: https://www.arca.fiocruz.br/handle/icict/20550 